\title{
Bibliometric Analysis of the Journal Acta Stomatologica Croatica: 2009-2018
}

\section{Bibliometrijska analiza časopisa Acta Stomatologica Croatica: od 2009. do 2018.}

\author{
${ }^{1}$ School of Dentistry, State University of Paraíba, Campina Grande, Brazil \\ Stomatološki fakultet Državnoga sveučilišta Paraíba, Campina Grande, Brazil \\ ${ }^{2}$ Head of Scientific and Research Centre of Forensic Dentistry, Faculty of Dentistry, Department of Prosthetic Dentistry, Uzhhorod National \\ University, Uzhhorod, Ukraine. \\ Zavod za zdravstvo i istraživanja u forencizi Državnoga sveučilišta u Užgorodu, Ukrajina
}

\section{Abstract}

Objective: To analyze a bibliometric profile of scientific production published in Acta Stomatologica Croatica (ASCRO). Material and methods: Scientific papers published from March 2009 to December 2018 were analyzed. Information on the year of publication was collected by four trained examiners. Dentistry area, study type and design, data analysis method, presence of randomization, number of authors and corresponding author affiliation were investigated. Data were analyzed using descriptive statistics. Results: A total of 328 articles were evaluated, with a predominance of research in the field of Dental Materials (16.5\%), with original article being the most frequent $(74.1 \%)$. Observational studies accounted for $52.4 \%$, using inferential statistics (83.2\%) and non-randomized experimental studies $(66.1 \%)$. Cross-sectional studies were more common in areas of Behavioral, Epidemiologic \& Health Services Research (86.3\%), case reports in Craniofacial Biology (54.0\%) and Oral Health Research (53.1\%), while in vitro studies were more common in the areas of Dental Materials $(90.7 \%)$, Microbiology / Immunology (70.0\%) and Cariology Research (66.7\%). Most articles were written by four authors (24.1\%), while foreign affiliation was observed in $53.0 \%$ of studies. Conclusion: The profile of ASCRO scientific production shows a predominance of original studies carried out in the areas of Dental Materials and Behavioral, Epidemiologic \& Health Services Research, with growing participation of foreign researchers.
Received: March 3, 2020

Accepted: May 2, 2020

Address for correspondence

Alessandro Leite Cavalcanti University Estadual da Paraíba, Programa de Pós-graduação em Odontologia.

Rua das Baraúnas, S/N - Bodocongó, Campina Grande, PB, Brazil, CEP 58429-500.

Tel.: +55 $833315-3326$

alessandrouepb@gmail.com

Key words

Publications; Bibliometrics; Journal Article; Dental Journalism

\section{Introduction}

Research is an investigative process used to increase or reassess current knowledge. The evolution of knowledge in a given area allows the development of not only important scientific and technological advances, but also generates great implications, both in the health and social spheres (1).

The way in which knowledge is constructed and disseminated is of paramount importance, since it will influence and guide thoughts, reflections and attitudes, shaping actions in all fields of knowledge (2). In the health sciences, the dissemination of new knowledge is firstly performed through scientific journals, specialized in the publication of original information and elaborated as research articles that have the ultimate goal of improving professional practice (3).

The search for the best scientific evidence in clinical decision-making in Dentistry has gained attention in recent years (4), with bibliometric analysis being an important tool that measures the level of development of a specific scientific field (5). Bibliometrics is a systematic method for evaluating re-
Uvod

Istraživanje je postupak koji se koristi za povećanje ili ponovnu procjenu trenutačnih znanja. Evolucija znanja u određenom području omogućuje razvoj ne samo važnih znanstvenih i tehnoloških postignuća, nego ima i velike implikacije kako na zdravstvenu, tako i na socijalnu sferu (1).

Način konstruiranja i širenja znanja iznimno je važan jer utječe i usmjerava misli, razmišljanja i stajališta te potiče akcije u svim znanstvenim područjima (2). U zdravstvu se širenje novih znanja uglavnom temelji na znanstvenim časopisima specijaliziranima za objavljivanje izvornih podataka i razrađenih znanstvenih članaka kojima je svrha profesionalno poboljšati praksu (3).

Posljednjih je godina pozornost privukla potraga za najboljim znanstvenim dokazima u kliničkom odlučivanju u stomatologiji (4), pri čemu je bibliometrijska analiza važna zato što se njome mjeri razina razvijenosti određenoga znanstvenog područja (5). Bibliometrija je sustavna metoda za procjenu rezultata istraživanja i može pomoći u bilježenju promje- 
search results, and it can help map the changes in a scientific community over time (6), since the information contained in this study type becomes a reference for future studies, which can focus on the type and quality of evidence published in dental journals (7).

The scientific journal Acta Stomatologica Croatica (ASCRO) was set up by the School of Dental Medicine of Zagreb and the Croatian Dental Society of the Croatian Medical Association, being continuously published since 1966, in a volume with four annual editions, with volume 7 being the only exception, published in 1972/73 (8). The journal is indexed in Pub Med Central, Chemical Abstracts, Directory of Open Access Journals, EBSCO and Scopus. Currently, articles are bilingual, in Croatian and English, making the journal more accessible to the world scientific community. ASCRO publishes editorials, original scientific articles, preliminary communications, reviews, professional articles and case reports, along with conference abstracts, professional information of interest, historical and memorial views (9).

ASCRO occupies the seventh place, according to the number of readers among journals in the area of Biomedicine and Health in Croatia (10). Thus, the aim of this study was to analyze the bibliometric profile of the scientific production published in Acta Stomatologica Croatica.

\section{Material and methods}

This is a descriptive research dealing with articles published in ASCRO from March 2009 to December 2018. Data were collected from the journal's website (http://www.ascro.hr/) and ten volumes were analyzed, with four annual editions (quarterly periodicity), totaling 40 issues.

Inclusion criteria were: selection of original research articles, which included preliminary communications and professional articles, literature review articles and case reports. Book reviews, reports of congresses and professional meetings, as well as summaries of congresses, editorials and letters to the editor were excluded.

Data collection was independently performed by four trained examiners. Information regarding the year of publication; area of Dentistry according to the International Association for Dental Research (IADR) (11); study type (original scientific article, review article and case report); study design (experimental, observational and documentary); data analysis method (descriptive and analytical); the presence of randomization (yes or no); number of authors and corresponding author affiliation (Croatian or foreign) were recorded.

Initially, the abstract of each publication was analyzed and on occasions when this analysis was not sufficient for data extraction, the article was fully read. When there was disagreement in the categorization, the decision was obtained by consensus among examiners.

Data were recorded on a form standardized in Microsoft Office Excel 2016 (Microsoft Press, Redmond, WA, USA) and analyzed using the IBM SPSS software (version 22.0 for Windows, IBM Corp., Armonk, NY, USA). A descriptive analysis was performed for categorical variables and measures of central tendency and variability for quantitative variables. na u znanstvenoj zajednici tijekom godina (6), jer informacije sadržane u toj vrsti istraživanja postaju referencija za buduća istraživanja koja se mogu usredotočiti na vrstu i kvalitetu dokaza objavljenih u stomatološkim časopisima (7).

Znanstveni časopis Acta Stomatologica Croatica (ASCRO) osnovali su Stomatološki fakultet u Zagrebu i Hrvatsko stomatološko društvo Hrvatskoga liječničkog zbora, a kontinuirano izlazi od 1966. četiri puta na godinu, s tim da je 7. svezak jedina iznimka - objavljen je 1972./73. (8). Časopis je indeksiran u PubMed Centralu, Chemical Abstractsu, Directory of Open Access Journalsu, EBSCO-u i Scopusu. Trenutačno su članci dvojezični - na hrvatskome i engleskome jeziku, što časopis čini dostupnijim svjetskoj znanstvenoj zajednici. ASCRO objavljuje uvodnike, izvorne znanstvene članke, preliminarna priopćenja, recenzije, stručne članke i izvještaje o slučajevima, zatim sažetke $s$ konferencija, zanimljive stručne podatke te povijesne i memorijalne prikaze (9).

ASCRO je na sedmom mjestu prema broju čitatelja među časopisima iz područja biomedicine i zdravlja u Hrvatskoj (10). Zato je cilj ovog istraživanja bio analizirati bibliometrijski profil znanstvene produkcije objavljene u časopisu Acta Stomatologica Croatica.

\section{Materijali i metode}

Ovo opisno istraživanje provedeno je na temelju članaka objavljenih u ASCRO-u od ožujka 2009. do prosinca 2018. Korišteni su podatci s internetske stranice časopisa (http:// www.ascro.hr/) i analizirano je deset svezaka s četiri godišnja izdanja (tromjesečna periodičnost), dakle, ukupno 40 brojeva.

Kriteriji za uključivanje bili su odabir izvornih članaka o istraživanju koji su obuhvaćali preliminarnu komunikaciju i stručne članke, članke za pregled literature i izvješća o slučajevima. Isključeni su bili recenzije knjiga, izvještaji s kongresa i stručnih skupova te sažetci kongresa, uvodni prilozi i pisma uredniku.

Prikupljanje podataka samostalno su obavila četiri educirana ispitivača. Usredotočili su se na podatke o godini izdavanja, područje stomatologije prema Međunarodnom udruženju za stomatološka istraživanja (IADR) (11), vrstu istraživanja (izvorni znanstveni članak, pregledni članak i izvješće o slučaju), nacrt istraživanja (eksperimentalni, promatrački i dokumentarni), metodu analize podataka (opisna i analitička) i randomizaciju (da ili ne), a bilježili su i broj autora i odgovarajuće autorsko podrijetlo (hrvatsko ili strano).

$\mathrm{Na}$ početku je analiziran sažetak svakoga članka, a ako to nije bilo dovoljno za bilježenje podataka, pročitan je cijeli. U slučaju nedoumica u kategorizaciji odluka je donesena konsenzusom ispitivača.

Podatci su bilježeni na standardiziranom obrascu u Microsoft Office Excelu 2016. (Microsoft Press, Redmond, WA, SAD) i analizirani $s$ pomoću softvera IBM SPSS (verzija 22.0 za Windows, IBM Corp., Armonk, NY, SAD). Deskriptivna analiza obavljena je za kategorijske varijable, a mjerene su središnje tendencije i varijabilnosti za kvantitativne varijable. 


\section{Results}

In the evaluation period, 328 articles were published, corresponding to an average of 32.8 papers / year, with a minimum of 28 and a maximum of 38 publications / year. Of these, $11.6 \%$ were published in 2018, followed by years 2015 and 2016, both with 11.0\%. Years 2012 and 2014 had the lowest percentage of scientific productions, with $8.5 \%$ each (Figure 1).

The predominant areas of Dentistry in studies were Dental Materials (16.5\%), followed by Behavioral, Epidemiologic \& Health Services Research (15.5\%) and Craniofacial Biology (11.3\%). In contrast, the areas of least representation were Evidence-Based Dentistry with $0.6 \%$ and Woman in Science with only $0.3 \%$ of articles (Figure 2). No studies in the areas of Network for Practice-Based Research, Neuroscience and Nutrition Research were found.

Regarding the characteristics of studies, there was a predominance of original articles (74.1\%), observational studies (52.4\%), analytical data analysis method (83.2\%) and most experimental studies were not randomized (66.1\%) (Table

\section{Rezultati}

U promatranom razdoblju objavljeno je 328 članaka, što u prosjeku iznosi 32,8 godišnje, s najmanje 28 i najviše 38 članaka na godinu. Od toga je 11,6 \% tiskano u 2018. godini, a slijede 2015. i 2016., obje s 11,0 \%. Godine 2012. i 2014. postotak znanstvene produkcije bio je najniži - 8,5\% (slika 1.).

Dominantna područja u istraživanjima ponajprije su stomatološki materijali (16,5\%), zatim ona o ponašanju, a slijede epidemiologija i zdravstvene usluge $(15,5 \%)$ te kraniofacijalna biologija (11,3\%). Suprotno tomu, teme s najmanjom zastupljenošću su stomatologija utemeljena na dokazima s $0,6 \%$ te žene u znanosti sa samo $0,3 \%$ članaka (slika 2.). Nisu pronađena istraživanja o područjima mreže za istraživanje utemeljene na praksi, neuroznanosti i prehrani.

Kad je riječ o obilježjima istraživanja, dominiraju izvorni članci $(74,1 \%)$, opservacijske studije $(52,4 \%)$ i metode analize analitičkih podataka $(83,2 \%)$, a većina eksperimentalnih istraživanja nije bila randomizirana $(66,1 \%)$ (tablica 1.). Od
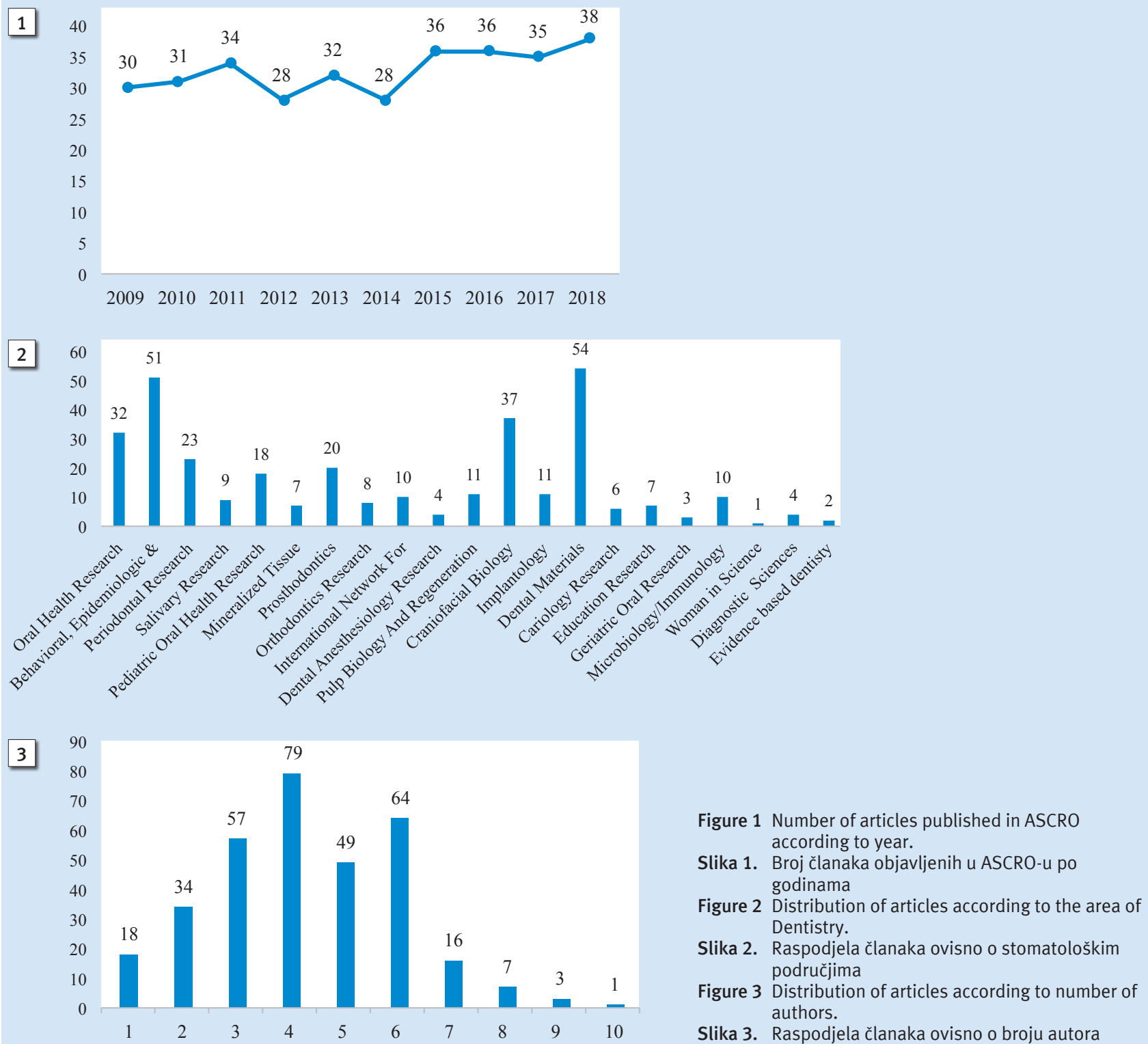
Table 1 Distribution of articles according to the characteristics of studies

Tablica 1. Raspodjela članaka ovisno o svojstvima istraživanja

Variables • Varijable

N

\begin{tabular}{c|c}
243 & 74.1 \\
12 & 3.6 \\
\hline 73 & 22.3
\end{tabular}

Article type $\bullet$ Tip članka

Original scientific article $\bullet$ Originalni znanstveni članak

Review article $\bullet$ Pregledni članak

Case report $\bullet$ Prikaz slučaja

Study design $\bullet$ Nacrt istraživanja

Observational $\bullet$ Promatračka

Experimental $\bullet$ Eksperimentalna

Documentary $\bullet$ Dokumentarna

Data analysis method $\bullet$ Metoda analize podataka

Descriptive $\bullet$ Deskriptivna

Analytical • Analitička

172

172

114

42

52.4

\begin{tabular}{l|r}
41 & 16.8 \\
\hline 203 & 83.2
\end{tabular}

Presence of randomization $\bullet$ Randomizacija

Yes $\bullet \mathrm{Da}$

$\mathrm{No} \cdot \mathrm{Ne}$

39

75

34.8

12.8

4.1

83.2

34.2

65.8

Table 2 Distribution of study designs according to area of Dentistry.

Tablica 2. Raspodjela nacrta istraživanja ovisno o stomatološkim područjima

\begin{tabular}{|c|c|c|c|c|c|c|c|c|c|c|c|c|c|}
\hline \multirow[b]{2}{*}{ Área da odontologia • Područje stomatologije } & \multicolumn{13}{|c|}{ Design $\bullet$ Nacrt } \\
\hline & $\begin{array}{c}\mathrm{Cr} \\
\text { Sec } \\
\mathrm{N}\end{array}$ & $\begin{array}{c}\text { Case } \\
\mathrm{Ct} \\
\mathrm{N}\end{array}$ & $\begin{array}{c}\mathrm{COH} \\
\mathrm{N}\end{array}$ & $\begin{array}{c}\text { Case } \\
\text { Rep } \\
\mathrm{N}\end{array}$ & $\begin{array}{c}\text { Case } \\
\text { Ser } \\
\mathrm{N}\end{array}$ & $\begin{array}{l}\text { IN } \\
\text { VIT } \\
\text { N }\end{array}$ & $\begin{array}{l}\text { IN } \\
\text { VIV } \\
\mathrm{N}\end{array}$ & $\begin{array}{c}\text { IN } \\
\text { VIT } \\
\text { IN } \\
\text { VIV } \\
\text { N }\end{array}$ & $\begin{array}{c}\text { Clin } \\
\text { Tr } \\
\text { N }\end{array}$ & $\begin{array}{c}\text { DOC } \\
\mathrm{N}\end{array}$ & $\begin{array}{l}\text { LR } \\
\mathrm{N}\end{array}$ & $\begin{array}{l}\text { SR } \\
\text { N }\end{array}$ & $\begin{array}{l}\text { Total } \\
\text { Ukupno } \\
\text { N }\end{array}$ \\
\hline Oral Health Research • Istraživanja oralnog zdravlja & 4 & 2 & 0 & 17 & 0 & 2 & 1 & 1 & 2 & 1 & 2 & 0 & 32 \\
\hline $\begin{array}{l}\text { Behavioral, Epidemiologic \& Health Services Research • } \\
\text { Istraživanja o ponašanju, epidemiologiji i zdravstvenim } \\
\text { uslugama }\end{array}$ & 44 & 1 & 0 & 0 & 0 & 0 & 0 & 0 & 2 & 4 & 0 & 0 & 51 \\
\hline Periodontal Research • Parodontološka istraživanja & 4 & 6 & 0 & 5 & 0 & 2 & 0 & 0 & 4 & 0 & 2 & 0 & 23 \\
\hline Salivary Research • Istraživanja sline i slinovnica & 0 & 2 & 0 & 0 & 0 & 2 & 0 & 0 & 4 & 0 & 1 & 0 & 9 \\
\hline $\begin{array}{l}\text { Pediatric Oral Health Research • Oralno zdravlje u } \\
\text { pedijatrijskim istraživanjima }\end{array}$ & 4 & 2 & 0 & 10 & 0 & 0 & 0 & 0 & 0 & 1 & 1 & 0 & 18 \\
\hline Mineralized Tissue $\bullet$ Mineralizirana tkiva & 1 & 0 & 0 & 1 & 0 & 4 & 0 & 0 & 0 & 0 & 1 & 0 & 7 \\
\hline Prosthodontics $\bullet$ Protetika & 6 & 0 & 0 & 7 & 0 & 0 & 0 & 0 & 2 & 4 & 1 & 0 & 20 \\
\hline Orthodontics Research $\bullet$ Ortodontska istraživanja & 2 & 2 & 0 & 0 & 0 & 1 & 0 & 0 & 0 & 3 & 0 & 0 & 8 \\
\hline $\begin{array}{l}\text { International Network for Orofacial Pain and Related } \\
\text { Disorders Methodology } \bullet \text { Međunarodna mreža za } \\
\text { metodologiju vezanu za poremećaje i orofacijalnu bol }\end{array}$ & 1 & 3 & 0 & 2 & 0 & 1 & 0 & 0 & 2 & 0 & 1 & 0 & 10 \\
\hline $\begin{array}{l}\text { Dental Anesthesiology Research • Istraživanje anestezije } \\
\text { zuba }\end{array}$ & 0 & 0 & 0 & 1 & 0 & 0 & 0 & 0 & 3 & 0 & 0 & 0 & 4 \\
\hline $\begin{array}{l}\text { Pulp Biology and Regeneration • Biologija zubne pulpe } \\
\text { i regeneracija }\end{array}$ & 0 & 0 & 0 & 3 & 0 & 5 & 1 & 0 & 1 & 0 & 1 & 0 & 11 \\
\hline Craniofacial Biology $\bullet$ Kraniofacijalna biologija & 4 & 2 & 0 & 20 & 1 & 0 & 0 & 0 & 2 & 5 & 2 & 1 & 37 \\
\hline Implantology • Implantologija & 0 & 1 & 0 & 3 & 0 & 0 & 0 & 0 & 6 & 0 & 1 & 0 & 11 \\
\hline Dental Materials $\bullet$ Zubni materijali & 1 & 0 & 0 & 0 & 0 & 49 & 0 & 0 & 2 & 1 & 0 & 1 & 54 \\
\hline Cariology Research • Istraživanja u karijesologiji & 1 & 0 & 0 & 0 & 0 & 4 & 0 & 0 & 0 & 1 & 0 & 0 & 6 \\
\hline Education Research • Istraživanja obrazovanja & 1 & 0 & 0 & 0 & 0 & 0 & 0 & 0 & 0 & 5 & 1 & 0 & 7 \\
\hline Geriatric Oral Research • Oralno-gerijatrijska istraživanja & 1 & 0 & 0 & 2 & 0 & 0 & 0 & 0 & 0 & 0 & 0 & 0 & 3 \\
\hline $\begin{array}{l}\text { Microbiology/Immunology } \bullet \text { Mikrobiologija/ } \\
\text { Imunologija }\end{array}$ & 0 & 1 & 0 & 0 & 0 & 7 & 0 & 0 & 2 & 0 & 0 & 0 & 10 \\
\hline Woman in science $\cdot$ Žene u znanosti & 0 & 0 & 1 & 0 & 0 & 0 & 0 & 0 & 0 & 0 & 0 & 0 & 1 \\
\hline Diagnostic Sciences $\bullet$ Dijagnostičke znanosti & 0 & 0 & 0 & 2 & 0 & 1 & 0 & 0 & 0 & 1 & 0 & 0 & 4 \\
\hline Evidence based Dentistry $\bullet$ Stomatologija po dokazima & 1 & 0 & 0 & 0 & 0 & 0 & 0 & 0 & 1 & 0 & 0 & 0 & 2 \\
\hline
\end{tabular}

$\mathrm{Cr} \mathrm{Sec}=$ Cross-Sectional; Case Ct = Case Control; $\mathrm{COH}=$ Cohort; Case Rep = Case Report; Cas Ser = Case Series; IN VIT = In vitro; IN VIV = In vivo; IN VIT IN VIV = In vitro and In vivo; Clin Tr = Clinical Trial; DOC = Documentary; $L R=$ Literature Review; $S R=$ Systematic Review 
1). Regarding the design of observational studies, 75 were cross-sectional, 73 were case reports, 22 control cases, 1 cohort and 1 case series. Clinical trials comprised 33, experimental in vitro comprised 78, in vivo comprised 2 and in vitro and in vivo comprised 1 . Of documentary studies, only two of them were systematic reviews.

Cross-sectional studies stood out as the design most frequently used in the area of Behavioral, Epidemiologic \& Health Services Research (86.3\%). Case reports represented the study type most used in the area of Craniofacial Biology (54.0\%) and Oral Health Research (53.1\%), and in vitro studies, in turn, in Dental Materials (90.7\%), Microbiology / Immunology (70.0\%) and Cariology Research (66.7\%) (Table 2).

Regarding authorship, the 328 articles included a total of 1407 authors, with an average of $4.29 \pm 1.75$ author / article, median of 4.00, minimum of 1 and maximum of $10 \mathrm{au}-$ thors. There was a greater number of articles with four authors (24.1\%) (Figure 3).

As for the corresponding author affiliation, there was a higher frequency of publications of foreign origin (53.0\%). Foreign studies were carried out in Brazil (25.9\%), Turkey (12.1\%), Greece (10.9\%), India (9.8\%), Bosnia (7.5\%), Thailand (4.0\%), Spain (4.0\%), Kosovo (3.4\%), Germany (2.9\%), Italy (2.9\%), Malaysia (2.3\%), Saudi Arabia (2.3\%), in Serbia (1.1\%), the United States of America (1.1\%). Other countries such as Poland, Bulgaria, Switzerland, Romania, Pakistan, Nigeria, Holland, Scotland, North Macedonia, Israel, Portugal, Slovenia, Libya, England, Albania, Sudan and Colombia accounted for $0.6 \%$ each.

\section{Discussion}

The strategy most used for the dissemination of research results is the publication of articles in scientific journals (12). There is significant growth in the dental literature for most bibliometric indices (13), and bibliometric analysis is capable of describing how a given scientific field is evolving, thus helping researchers to identify changing research focuses, as well as knowledge gaps (14).

A previous study involving the ASCRO bibliometric analysis from 1987 to 2006 revealed an average of 35.6 articles per year (15). It was found in this study that the scientific production of the journal during the analyzed period increased considerably. The following can be considered as possible reasons related to this result: significant changes in ASCRO over these 10 years such as indexation in Scopus (Elsevier) in 2009; the creation of a website, enabling the access of the scientific community to the journal at any time and any place; the inclusion in the Cross Ref system and the adoption of its own DOI number (Digital Object Identifier), in 2014, making documents permanently available (16); indexation in Pub Med Central (PMC), which increased its visibility in 2016; and inclusion in the ESCI (Emerging Sources Citation Index), which is an integral part of the Web of Science Core Collection (Clarivate Analytics), in 2018 (8).

These changes in ASCRO affected its visibility and a gradual increase in the number of published articles confirms the quality of the journal, which is well accepted by research- nacrta opservacijskih istraživanja 75 je bilo presječnih, 73 su bila prikazi slučajeva, 22 kontrolni slučajevi, te jedno kohortno i jedan serijski niz slučajeva. Kliničkih ispitivanja obavljeno je 33, eksperimentalnih istraživanja in vitro 78 , in vivo $\mathrm{dva}$, a in vitro i in vivo jedno. Od dokumentiranih istraživanja samo su dva bila sustavno pregledna.

Poprečno-presječna istrǎ̌ivanja istaknuta su kao ona koja se najčešće koriste u području istraživanja ponašanja, epidemiologije i zdravstvenih usluga $(86,3 \%)$. Prikazi slučajeva bili su najčešći oblik istraživanja u području kraniofacijalne biologije $(54,0 \%)$ i oralnoga zdravlja $(53,1 \%)$, a istraživanja in vitro kad je riječ o dentalnim materijalima $(90,7 \%)$, mikrobiologiji/imunologiji $(70,0 \%)$ i istraživanjima karijesa $(66,7$ \%) (tablica 2.).

Kad je riječ o autorstvu, 328 članaka napisalo je ukupno 1407 autora, prosječno $4,29 \pm 1,75$ autora po članku, medijan je bio 4,00, $s$ najmanje jednim i najviše 10 autora. Najviše su članaka zajednički napisala četiri autora $(24,1 \%)$ (slika 3.).

$\mathrm{U}$ vezi s autorskom pripadnošću, najviše je bilo stranih članaka $(53,0 \%)$. Strana istraživanja provedena su u Brazilu (25,9 \%), Turskoj (12,1\%), Grčkoj (10,9\%), Indiji (9,8 \%), Bosni i Hercegovini (7,5\%), Tajlandu (4,0\%), Španjolskoj (4,0 \%), Kosovu (3,4\%), Njemačkoj (2,9\%), Italiji (2,9 $\%)$, Maleziji (2,3 \%), Saudijskoj Arabiji (2,3\%), Srbiji (1,1 $\%)$ i Sjedinjenim Američkim Državama (1,1\%). Ostale zemlje poput Poljske, Bugarske, Švicarske, Rumunjske, Pakistana, Nigerije, Nizozemske, Škotske, Sjeverne Makedonije, Izraela, Portugala, Slovenije, Libije, Engleske, Albanije, Sudana i Kolumbije imale zastupljenost od po 0,6 \%.

\section{Rasprava}

Strategija koja se najčešće koristi za širenje rezultata istraživanja jest objavljivanje članaka u znanstvenim časopisima (12). Ističemo znatan porast stomatološke literature u većini bibliometrijskih indeksa (13), a na temelju bibliometrijske analize može se opisati razvoj određenoga znanstvenog područja, te se tako pomaže istraživačima da utvrde promjenjiva istraživačka težišta i nedostatke u znanju (14).

U ranijem istraživanju koje je obuhvatilo bibliometrijsku analizu ASCRO-a od 1987. do 2006. godine, zabilježeno je u prosjeku 35,6 članaka godišnje (15). U ovom istraživanju utvrđeno je da se znanstvena produkcija časopisa tijekom analiziranog razdoblja znatno povećala. Razlozi za to mogu biti sljedeći: značajne promjene u ASCRO-u tijekom proteklih 10 godina, poput indeksacije u Scopusu (Elsevier) u 2009. godini, internetska stranica koja omogućuje znanstvenoj zajednici pristup časopisu u bilo koje vrijeme i na bilo kojem mjestu, uključivanje u sustav CrossRef $i$ usvajanje vlastita broja DOI (Digital Object Identifier) 2014. godine, čime su dokumenti trajno dostupni (16). Tu je i indeksacija u Pub Med Centralu (PMC), što je povećalo vidljivost ASCRO-a u 2016. godini te uključivanje u ESCI (Emerging Sources Citation Index) koji je dio Web of Science Core Collectiona (Clarivate Analytics) u 2018. godini (8).

Navedene promjene u ASCRO-u utjecale su na njegovu vidljivost i postupno povećavanje broja objavljenih članaka. $\mathrm{Na}$ taj je način potvrđena kvaliteta časopisa koju su istraživa- 
ers and professionals and has consolidated editorial policy, receiving support from the School of Dental Medicine of $\mathrm{Za}$ greb, the Croatian Medical Association and the Ministry of Science, Education and Sports (16). Currently, the demand to "publish or perish" in the academic community may also have driven the increase in dental productivity (13).

The most frequently studied areas of Dentistry were Dental Materials and Behavioral, Epidemiologic \& Health Services Research. The science that involves dental materials aims to explore and develop biomaterials that will be used in the oral cavity (17). This greater focus on the area of dental materials may be related to high competition among technological innovation companies, mainly in the field of nanotechnology, which has promoted rapid progress in the area of biomaterials, providing the development of new materials and devices for biomedical applications, in addition to greater knowledge about the interaction between biomaterials and biological tissues (17). New materials have been daily launched and the application of dental biomaterials on gingival, mucous and hard tissues may constitute a risk if the professional does not master the characteristics, concentrations and inherent properties of materials (18). In this context, advances in the area allow dentists to use innovative therapies, restoring the physical, psychological and social well-being of patients.

In this research, the area of Epidemiology showed significant representativeness. Despite being a relatively new field, the study of Epidemiology was stimulated by the growing concern with public health (19). These studies are important because they seek to identify the causes of a disease in order to deepen the understanding and improve population's health through numerous applications in the field of public health related to the planning and evaluation of health services (19).

However, there are areas which are not sufficiently explored, such as Evidence-Based Dentistry and Woman in Science, which is a gap in scientific knowledge. Thus, greater incentive to research and dissemination of scientific production in these areas is necessary in order to increase the journal's impact.

Most published articles were cross-sectional studies that presented limitations as to the fact that they are performed at a certain time, which did not allow inferring causality (20). However, they are quick and had low cost to estimate the prevalence of oral health problems, identify treatment and serve as source of planning and organization for public oral health policies (20).

In vitro studies accounted for the majority of experimental research, but although they are necessary, as they precede research on human beings, they are not able to determine or there is a limitation for determining the clinical effect of experiments, and they often become repetitive due to the high number of surveys $(21,22)$.

The pyramid of scientific evidence determines the hierarchy or levels of evidence in its structure. These levels are organized in ascending order of internal validity, with randomized clinical trials, systematic reviews and meta-analyses representing the highest level of evidence available (23). A small number of clinical trials and systematic reviews were observed in the present research, a fact that may be associated with the difficulty of their execution, since these are studies či i stručnjaci dobro prihvatili i ojačali uredničku politiku, te dobili potporu Stomatološkog fakulteta u Zagrebu, Hrvatskoga liječničkog saveza i Ministarstva znanosti, obrazovanja i športa RH (16). Možda je i potreba za objavom ili propadanjem u akademskoj zajednici također potaknula porast produktivnosti kod stomatologa (13).

Najčěšce proučavana stomatološka područja su materijali i istraživanja o ponašanju, epidemiologiji i zdravstvenim uslugama. Znanosti koja uključuje stomatološke materijale svrha je istražiti i razviti biomaterijale koji će se primjenjivati u usnoj šupljini (17). Taj pojačani fokus na područje stomatoloških materijala može biti povezan $s$ velikom konkurencijom među tehnološkim inovacijskim tvrtkama, uglavnom u području nanotehnologije. To je potaknulo brz napredak u istraživanju biomaterijala i osiguralo razvoj novih materijala i uređaja za biomedicinsku primjenu, te stjecanje sve kompleksnijeg znanja o interakciji između biomaterijala i bioloških tkiva (17).

Svakodnevno se pojavljuju novi stomatološki materijali, a primjena tih biomaterijala na gingivi, sluznici i tvrdom tkivu može biti rizična ako stručnjak ne poznaje koncentraciju, te pojedinačna i zajednička svojstva materijala (18). U tom kontekstu, napredak u tom području omogućuje stomatolozima da se koriste inovativnim terapijama, vraćajući pacijentima fizičku, psihološku i socijalnu komponentu dobrobiti.

$\mathrm{U}$ ovom istraživanju je područje epidemiologije pokazalo značajnu reprezentativnost. Iako je to razmjerno novo područje, proučavanje epidemiologije potaknulo je sve veću zabrinutost za javno zdravstvo (19). Istraživanja o toj temi važna su zato što njihovi autori nastoje ustanoviti uzroke bolesti kako bi se produbilo razumijevanje i poboljšalo zdravlje stanovništva primjenom u javnom zdravstvu, a to se odnosi na planiranje i procjenu zdravstvenih usluga (19).

Postoje i područja koja se rijetko istražuju, poput stomatologije utemeljene na dokazima i ona o ženama u znanosti, što je svakako nedostatak u znanstvenim spoznajama. Zato je potreban veći poticaj za istraživanje i širenje znanstvene proizvodnje u tim područjima kako bi se povećao učinak časopisa.

Većina objavljenih članaka bila su presječna istraživanja koja su imala ograničenja zbog činjenice da se provode u određeno vrijeme, što nije dopuštalo zaključke o uzročno-posljedičnoj povezanosti (20). No to su brza istraživanja uz male troškove i služe za procjenu učestalosti oralnih zdravstvenih problema i identifikaciju vrsta liječenja te kao osnova za planiranje i organiziranje smjernica javnih politika za oralno zdravlje (20).

Istraživanja in vitro činila su većinu eksperimentalnih istraživanja, ali iako su nužna zato što prethode istraživanju na ljudima, njihovi autori nisu u mogućnosti odrediti postoji li ograničenje za određivanje i klinički učinak eksperimenata, a često se i ponavljaju zbog velikoga broja anketa $(21,22)$.

Piramida znanstvenih dokaza određuje hijerarhiju ili razinu dokaza u njezinoj strukturi. Te su razine organizirane uzlaznim redoslijedom unutarnje valjanosti, $s$ randomiziranim kliničkim ispitivanjima, sustavnim preglednim člancima i metaanalizama, te su najviša razina dostupnih dokaza (23). U ovom je istraživanju uočeno malo kliničkih ispiti- 
that require more time and cost, requiring greater experience for their execution, as well as a research group well prepared for their development (24).

It could be expected that the number of well-conducted clinical trials will be even lower, considering criteria related to the randomization of experimental groups, since most experimental studies found were not randomized. Therefore, it is necessary to encourage researchers to publish the gold standard study types for an evidence-based practice.

ASCRO's bibliometric analysis in the 1987-2006 period showed that 711 articles were written by 1136 authors, corresponding to 3.3 authors / article (8). In the present study, the average number of authors / article was 4.29. A recent study carried out with Brazilian researchers with notorious scientific production indicated that they consider four the ideal number of co-authors to enhance scientific production (25). Collaboration among authors makes research more visible, since coauthors add their scientific knowledge, enabling deeper evaluations, which, consequently, create more favorable conditions for the production of high-quality works (26).

Regarding the corresponding author affiliation, there was a prevalence of publications of foreign origin and, among these, there was a predominance of Brazilian researchers. Over the years, Brazil has grown considerably in the field of scientific production. According to data from SC Imago Journal and Country Rank, the country ranks $2^{\text {nd }}$ position, with most international articles published in Dentistry (27). The increase in the number of scientific publications by Brazilian researchers reflects the role of incentives implemented by Brazilian funding agencies, with emphasis on the development of national graduate programs and the granting of research productivity grants by CNPq (National Council for Scientific and Technological Development), as a way of motivating researchers (28).

A high number of studies of foreign origin may indicate the journal's visibility worldwide. Free access to the journal through the Portal of Scientific Journals of the Republic of Croatia (Hrčak), a central portal that brings together Croatian scientific and professional journals that offer open access, as well as the publication of the online version of the journal and the digitization of the entire collection since the first year has increased the interest of researchers in publications, increasing the relevance of ASCRO in the scientific community and allowing the increase in the number of authors in its editions (8). Indexing in global databases has also expanded the journal's worldwide relevance (8); another factor is that there are no fees for submission or publication of articles.

According to Borić and Stefić (8), the use of Cross-ref Similarity Check, software that facilitates the recognition of articles that contain plagiarized data will also raise the standard of acceptance of articles and will have a high impact on the future of the journal.

It is important to highlight the fact, which is a limitation of the present article, that this study considers the corresponding author as a way of identifying the institutional affiliation of authors, consequently, some studies may have been inadequately categorized, as there is the possibility of having collaborators of different nationalities in the same article. vanja i sustavnih preglednih članaka, što može biti posljedica poteškoća u njihovoj provedbi, jer su to vrste istraživanja koje zahtijevaju više vremena i troškova, a za njihovu provedbu potrebno je veće iskustvo i dobro pripremljena istraživačka skupina (24).

Moglo je biti još manje dobro provedenih kliničkih ispitivanja ako se uzmu u obzir kriteriji vezani za randomizaciju eksperimentalnih skupina, jer većina nađenih eksperimentalnih studija nije bila nasumična. Zato je potrebno poticati istraživače na objavljivanje istraživanja o zlatnim standardima za praksu i sve temeljiti na dokazima.

ASCRO-ova bibliometrijska analiza u razdoblju od 1987. do 2006. pokazala je da je 711 članaka napisalo 1136 autora, što je 3,3 autora po članku (8). U ovom je istraživanju prosječan broj autora po članku bio 4,29. U nedavnom istraživanju o neprimjerenom broju autora u znanstvenoj produkciji koje su proveli brazilski istraživači, pokazalo se da se četiri autora smatraju idealnim brojem suautora za poboljšanje znanstvene produkcije (25). Suradnja među autorima čini istraživanje vidljivijim, jer suautori dodaju svoje znanstvene spoznaje te tako omogućuju dublje procjene, što posljedično stvara povoljnije uvjete za proizvodnju visokokvalitetnih radova (26).

U vezi s odgovarajućom autorskom pripadnošću, tiskani su uglavnom tekstovi stranih autora, a među njima su prevladavali brazilski. Može se reći da se proteklih godina Brazil znatno češće pojavljuje u području znanstvene proizvodnje. Prema podatcima SC Imago Journala i Country Ranka, zemlja se nalazi na drugom mjestu, a većina obavljenih međunarodnih radova odnosi se na stomatologiju (27). Povećanje broja znanstvenih radova brazilskih istraživača pokazuje koliko su važni poticaji tamošnje Agencije za financiranje s naglaskom na razvoj nacionalnih diplomskih programa i dodjelu stipendija za produktivnost $\mathrm{u}$ istraživanju, što čini CNP-q (Nacionalno vijeće za znanstveni i tehnološki razvoj) kao način za motiviranje istraživača (28).

Velik broj stranih istraživanja može upućivati na preglednost časopisa na svjetskoj razini. Besplatan pristup časopisu na Portalu znanstvenih časopisa Republike Hrvatske (Hrčak), središnjem portalu koji objavljuje hrvatske znanstvene i stručne časopise koji nude otvoren pristup, te objavljivanje internetske verzije časopisa i digitalizacija cijele zbirke od prve godine, potaknula je veće zanimanje istraživača za časopis, povećala je relevantnost ASCRO-a u znanstvenoj zajednici te omogućila povećanje broja autora u njegovim izdanjima (8). Indeksiranje u globalnim bazama podataka također je proširilo svjetsku relevantnost časopisa (8). Drugi važan čimbenik jest da nema naknade za slanje ili objavljivanje članaka.

Prema Boriću i Štefiću (8), upotreba Crossrefove provjere sličnosti, softvera koji olakšava prepoznavanje članaka koji sadržavaju plagirane podatke, također će podignuti standard pri prihvaćanju članaka i znatno će utjecati na budućnost časopisa.

Važno je istaknuti, kao ograničenje u ovom radu, činjenicu da se ovo istraživanje autora za korespondenciju smatra načinom identificiranja njihove institucionalne pripadnosti, pa su zato neke studije možda netočno kategorizirane jer postoji i mogućnost da na istom tekstu surađuju autori nekoliko različitih nacionalnosti. 


\section{Conclusion}

The profile of ASCRO's scientific production shows a predominance of original studies carried out in the areas of Dental Material, Behavioral, Epidemiologic \& Health Services Research, with growing participation of foreign researchers.

\section{Conflict of interest}

The authors declare that they have no conflict of interest.

\section{Zaključak}

Profil znanstvene produkcije ASCRO-a pokazuje da prevladavaju izvorna istraživanja o stomatološkim materijalima te bihevioralnim, epidemiološkim i zdravstvenim uslugama, uz sve veće sudjelovanje stranih istraživača.

\section{Sukob interesa}

Autori izjavljuju da nisu bili u sukobu interesa.

\section{Sažetak}

Cilj: Analiza bibliometrijskog profila znanstvene proizvodnje objavljenog u časopisu Acta Stomatologica Croatica (ASCRO). Materijal i metode: Istraživanja su provedena na temelju članaka objavljenih od ožujka 2009. do prosinca 2018. godine. Informacije su prikupila četiri educirana ispitivača - zanimali su ih podatci o godini objavljivanja, o području stomatologije, vrsti i dizajnu studije, metodi analize podataka, randomizaciji, broju autora i njihovoj razvrstanosti prema zemljama. Podatci su analizirani s pomoću opisne statistike. Rezultati: Ukupno je ocijenjeno 328 članaka, uglavnom su se istraživali zubni materijali (16,5\%), a izvornih je članaka bilo najviše (74,1 \%). Među promatranim istraživanjima bilo je $52,4 \%$ onih u kojima su se koristili statistički podatci, o infekciji ih je bilo $83,2 \%$, a nerandomizirane eksperimentalne studije činile su $66,1 \%$. Presječna istraživanja češća su za područja bihevioralnog, epidemiološkog i zdravstvenog osiguranja (86,3 \%), zatim kad je riječ o slučajevima kraniofacijalne biologije $(54,0 \%)$ i oralnim zdravstvenim istraživanjima $(53,1 \%)$, a studije in vitro češće su u područjima stomatoloških materijala (90,7 \%), mikrobiologije/imunologije $(70,0$ \%) i karioloških istraživanja $(66,7 \%)$. Većinu članaka pisala su zajednički četiri autora $(24,1 \%)$, a suradnja sa stranim stručnjacima zabilježena u 53,0 \% istraživanja. Zaključak: Profil znanstvene proizvodnje ASCROa pokazuje dominaciju izvornih studija provedenih u područjima stomatoloških materijala i istraživanja o ponašanju, epidemiologiji i zdravstvenim uslugama, uz sve veće sudjelovanje stranih istraživača.
Zaprimljen: 3. ožujka 2020. Prihvaćen: 11. svibnja 2010.

Adresa za dopisivanje Alessandro Leite Cavalcanti Universidade Estadual da Paraíba, Programa de Pós-graduação em Odontologia.

Rua das Baraúnas, S/N - Bodocongó, Campina Grande, PB, Brazil, CEP 58429-500.

tel.: +55 83 3315-3326 alessandrouepb@gmail.com

Ključne riječi publikacije; bibliometrija, članak u časopisu; stomatološko izdavaštvo

\section{References}

1. Castro Y, Chale-Yaringa NA, Gonzales UP. Producción científica en periodoncia e implantes a nivel de Iberoamérica. Rev Clin Periodoncia Implantol Rehabil Oral. 2016 Apr;9(2):114-120.

2. Costa RM, Vieira RS, Cavalcanti AN. Perfil da pesquisa acadêmica odontológica da EBMSP. Revista da ABENO 2015;15(1):70-76.

3. Gomes PB, Ferreira SH, Poletto VC, Bervian J, Kramer PF. Bibliometric evaluation of the scientific production of the Stomatos Dental Journal. Stomatos 2011 Jul/Dez;17(33):20-31.

4. Kramer PF, Feldens CA, Ilha MC, Borges TS, Cavalcanti AL. Bibliometric analysis of the scientific production of the Pesquisa Brasileira em Odontopediatria e Clinica Integrada: 2007-2017. Pesqui Bras Odontopediatria Clin Integr. 2018 Oct;18(1):e4441.

5. Araújo RF, Alvarenga L. A bibliometria na pesquisa científica da pós-graduação brasileira de 1987 a 2007. Enc. Bibli: R Eletr Bibliotecon Ci Inf. 2011 Mar;16(31):51-70.

6. Thomas J, Walker TW, Miller S, Cobb A, Thomas SJ. The Olympic legacy: Journal metrics in sports medicine and dentistry. J Int Soc Prevent Communit Dent. 2016 Nov/Dec;6(6):501-508.

7. Uribe S, Pradenas I, Urriola M. Impacto del aumento de escuelas de odontología en la productividad científica odontológica chilena. Revista Clínica de Periodoncia, Implantología y Rehabilitación Oral. 2012 Apr;5(1):13-19.

8. Borić V; Štefić L. The First Fifty Years of the Journal Acta Stomatologica Croatica (1966 - 2016): Citation Analysis. Acta Stomatologica Croatica. 2018 Dec;52(4):348-357.

9. Boric V, Strujic M. Acta Stomatologica Croatica 1987-2019: Online Bibliography. [serial on the Internet]. 2019. Available from: http://bib.ascro.hr/about

10. MeSH Browser [database on the Internet]. HRCAK. Posjećenost časopisa u razdoblju: 01.08.2019. - 31.08.2019., biomedicina i zdravstvo. 2019. [cited 2019 Nov 03]. Available from: https:// hrcak.srce.hr/index.php?show=posjecenost-casopisa\&mjesec o d $=8$ \& godina od $=2019 \&$ mjesec do $=8 \&$ godina do $=2019 \&$ podrucje $=3$.

11. MeSH Browser [database on the Internet]. International Association for Dental Research. IADR SCIENTIFIC GROUP/NETWORK AWARDS. 2019. [cited 2019 Oct 15]. Available from: https:// www.iadr.org/IADR/Awards/Scientific-Group-Network-Awards

12. Faggion CM, Málaga L, Monje A, Trescher AL, Listl S, Alarcón MA. The 300 most cited articles published in periodontology. Clin Oral Investig. 2017 Jul;21(6):2021-2028.
13. Jayaratne YSN, Zwahlen RA. The Evolution of Dental Journals from 2003 to 2012: A Bibliometric Analysis. PLoS ONE 2015 Mar;10(3):e0119503.

14. Celeste RK, Broadbent JM, Moyses SJ. Half-century of Dental Public Health research: bibliometric analysis of world scientific trends. Community Dent Oral Epidemiol. 2016 Dec;44(6):557-563.

15. Boric V, Strujic M. Bibliometric Analysis of Acta Stomatologica Croatica: 1987-2006. Acta Stomatol Croat. 2006;40(4):336-46.

16. Boric V. 50th Anniversary of Acta stomatologica Croatica. Acta Stomatol Croat. 2016 Mar;50(1):2-7.

17. Sinhoreti MAC, Vitti RP, Sobrinho LC. Biomateriais na Odontologia: panorama atual e perspectivas futuras. Rev Assoc Paul Cir Dent. 2013 Oct;67(3):178-186.

18. Bugarin Júnior JG, Garrafa V. Bioética e biossegurança: uso de biomateriais na prática odontológica. Rev. Saúde Pública. 2007 Apr;41(2), 223-228.

19. Veiga N, Coelho I. The Importance of Epidemiology in Dental Medicine. J Dent Oral Health. 2015 Jan;1(4):1-4.

20. Levin KA. Study design III: cross-sectional studies. Evid Based Dent. 2006 Mar;7(1):24-25.

21. Oliveira GJ, Oliveira ES, Leles CR. Survey of study design of papers published in Brazilian dental journals. Rev Odonto Cienc. 2007;22(55):42-7.

22. Rode SM. Editorial. Pesq Odontol Bras. 2000;14(supl):1.

23. Mulimani PS. Evidence-based practice and the evidence pyramid: A 21st century orthodontic odyssey. Am J Orthod Dentofacial Orthop. 2017 Jul;152(1):1-8.

24. Nedel WL, Silveira F. Os diferentes delineamentos de pesquisa e suas particularidades na terapia intensiva. Rev Bras Ter Intensiva. 2016 Jun;28(3):256-260.

25. Hilário CM, Gracio MCC. Scientific collaboration in Brazilian researches: a comparative study in the information science, mathematics and dentistry fields. Scientometrics. 2017 Sep;113(1):929950.

26. Pan RK, Kaski K, Fortunato S. World citation and collaboration networks: Uncovering the role of geography in science. Scientific Reports 2012 Nov;2:902.

27. MeSH Browser [database on the Internet]. Scimago Journal \& Country Rank. 2019. [cited 2019 Nov 03]. Available from: http:// www.scimagojr.com

28. Souza JGS, Veloso Popoff DA, Nunes Oliveira RC, de Almeida ER, Junior HM, Lima AMEB. Profile and scientific production of Brazilian researchers in dentistry. Arq Odontol. 2016 Jan;52(1):13-22. 